\title{
EFFECT OF ELECTRONIC RADIATION ON THE EVOLUTION OF NANOSTRUCTURE AND CREEP OF Zr AT THE TEMPERATURE OF $670 \mathrm{~K}$
}

\author{
E.V. Karaseva, A.V. Mats, V.A. Mats, E.S. Savchuk, V.I. Sokolenko, D.V. Titov \\ National Science Center "Kharkov Institute of Physics and Technology", \\ Kharkiv, Ukraine \\ E-mail: vsokol@kipt.kharkov.ua
}

\begin{abstract}
The effect of electron irradiation on the creep and evolution of the zirconium nanostructure obtained by the SPD method and previously relaxed by ultrasound is studied. It has been shown that the electron irradiation (with a dose of $D=5 \cdot 10^{19} \mathrm{~cm}^{-2}$ and energy $E=10 \mathrm{MeV}$ ) does not change the character of the deformed zirconium nanostructure, but initiates the return processes at the grain boundaries and in the border areas, which leads to the softening of the material. The previously relaxation of internal stresses by ultrasound allows one to preserve a sufficiently high level of the strength and plasticity of nanostructured $\mathrm{Zr}$ after electron irradiation by reducing the intensity of dynamic recrystallization and activating an additional slip system in the creep process at $670 \mathrm{~K}$.
\end{abstract}

PACS: 62.20.HG, 61.72.FF, 61.10.-I

\section{INTRODUCTION}

The need to create materials with the highest radiation resistance and providing the required service life of fuel cladding systems is one of the main tasks of reactor materials science. It is known that the degradation of the initial physicomechanical properties of products in the process of irradiation is determined by changes in the composition and structure of materials.

Now, a large amount of theoretical and experimental investigation on the physical nature and mechanisms of radiation defects and radiation-stimulated phenomena occurring in materials under irradiation have been performed [1].

Based on the information obtained, physical ideas about the mechanisms of radiation defect to solids were formed and two approaches to the creation of new reactor materials with the required physical and mechanical properties were reasonably chosen. The first approach is to create new alloys and compounds, and the second is to change the properties of traditional materials by modifying the structure. The latter method is particularly interesting and promising for zirconium and its alloys with niobium, having a low effective neutron capture cross section, high thermomechanical and corrosion resistance, and good processability.

The features of the processes of zirconium deformation and the characteristics of the deformation structure are detail studied [2-4]. The improvement in the exploitative characteristics of zirconium products is currently connected to the development of methods for the formation of micro- and nanocrystalline structures that have unique mechanical properties which are very different from the properties of coarse-grained polycrystalline materials. The prospects for using nanostructured zirconium and its alloys as structural materials are determined by the degree of knowledge of the characteristics of their behavior under conditions close to exploitative ones. Knowledge of the nature and laws of transformation of nanostructures under electron irradiation will allow drawing conclusions about the processes of microplastic flow, linking them with structural elements, as well as analyzing radiation- stimulated changes in mechanical properties from the point of view of dislocation kinetics [5, 6].

In order to obtain express information on the radiation resistance of structural materials, electron accelerators are widely used. In the process of irradiation with a beam of charged particles, it is possible to reproduce and investigate under well controlled conditions practically all known radiation effects and their physical nature. Simulation experiments along with reactor tests make a significant contribution to the study of radiation physics and the development of radiation technologies, as well as solving the problems of creating new materials with high radiation resistance.

The purpose of this work is to establish the laws of creep and evolution of zirconium nanostructures obtained using rolling and subsequent electron irradiation, as well as ultrasonic impact treatment (UIT).

\section{MATERIAL AND PROCESSING METHOD}

The investigated material was the polycrystalline $\mathrm{Zr}$ obtained by electron beam melting. With the purpose of maximally effects on structure and properties were used next modes of treatments:

1. MT-1 - combined rolling at $77 \ldots 300 \mathrm{~K}$, finite deformation $(\varepsilon)$ was 3.9;

2. MT-2 - MT-1 + electron irradiation with $E=10 \mathrm{MeV}$ and dose $D=5 \cdot 10^{19} \mathrm{~cm}^{-2}$;

3. MT-3 - MT-1 + UIT at $300 \mathrm{~K}$;

4. MT-4 - MT-3 + electron irradiation with $E=10 \mathrm{MeV}$ and dose $D=5 \cdot 10^{19} \mathrm{~cm}^{-2}$.

The creep tests were carried out in the step loading regime at $670 \mathrm{~K}$ that corresponds to the reactor operating temperature, the measurement accuracy was $5 \cdot 10^{-5} \mathrm{~cm}$.

The samples were irradiated by electron beam with an energy of $E=10 \mathrm{MeV}$ at a temperature not exceeding $90^{\circ} \mathrm{C}$ for $315 \mathrm{~h}$ with a dose set of $D=$ $5 \cdot 10^{19} \mathrm{~cm}^{-2}$. The choice of this energy is due to the activation threshold for zirconium $\sim 12 \mathrm{MeV}$ [7]. The choice of the radiation dose $D=5 \cdot 10^{19} \mathrm{~cm}^{-2}$ was determined by the fact that the most intensive influence 
on the mechanical properties of zirconium is exerted by radiation with relatively small fluence [8].

A part of rolled samples were subjected to UIT $(f=20 \mathrm{kHz})$ at $T=300 \mathrm{~K}$ using the technique described in the work [5]. The amplitude of ultrasonic tangential stresses was $70 \mathrm{MPa}$, the UIT duration was $10 \mathrm{~min}$. A selected mode of preliminary ultrasonic treatment $[9,10]$ exerts a softening effect on the deformed material. The structure evolution control was carried out using the electron microscopic method.

\section{RESULTS AND DISCUSSION}

On Fig. 1 the creep rate at $670 \mathrm{~K}$ of the zirconium samples after all MT in all investigational intervals of stresses are present.

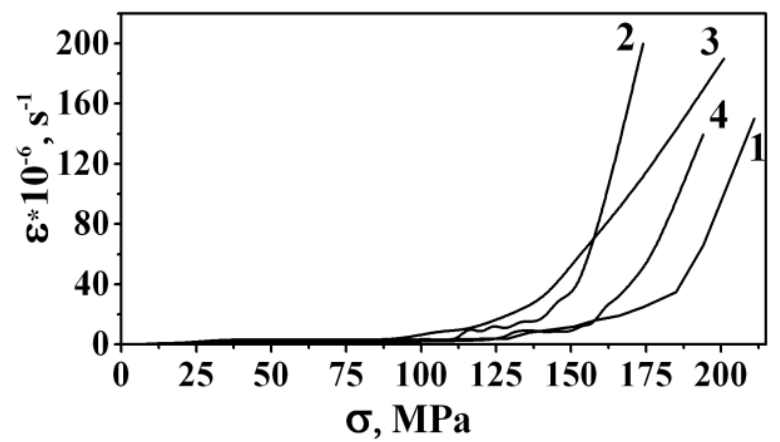

Fig. 1. Creep rates at $T=670 \mathrm{~K}$ as a function of the applied stress for the nanostructured $\mathrm{Zr}$ subjected to different treatments:

$1-M T-1 ; 2-M T-2 ; 3-M T-3 ; 4-M T-4$

As seen, the irradiation of nanostructured $\mathrm{Zr}$ by electrons with a dose of $D=5 \cdot 10^{19} \mathrm{~cm}^{-2}$ and energy $E \sim 10 \mathrm{MeV}$ (MT-2) leads to the decrease in the strength characteristics and creep rate at the test temperature of $670 \mathrm{~K}$, while the plasticity of the material has not changed much.

It was showed [11-13] that the treatment of nanostructured materials by UIT also leads to softening, but it allows one to retain a sufficiently high plasticity and uniformity of the material, with an increase in structural stability in the course of plastic flow. The treatment of zirconium samples by UIT (MT-3), the same as in [11-13], was performed in this work (see Fig. 1, curve 3).

Then, these samples were irradiated by electrons with thedose of $D=5 \cdot 10^{19} \mathrm{~cm}^{-2}$ and the energy $E \sim 10 \mathrm{MeV}$ (MT-4), in order to study the stability to irradiation of the structure relaxed by UIT.

Mechanical characteristics of nanostructured $\mathrm{Zr}$ at $T=670 \mathrm{~K}$ after different treatments

\begin{tabular}{|c|c|c|c|}
\hline $\begin{array}{c}\text { Modes of } \\
\text { treatment }\end{array}$ & $\sigma_{0.2}, \mathrm{MPa}$ & $\sigma_{\mathrm{s}}, \mathrm{MPa}$ & $\varepsilon, \%$ \\
\hline MT-1 & 132 & 211 & 8.5 \\
\hline MT-2 & 114 & 174 & 9.0 \\
\hline MT-3 & 102 & 201 & 16.3 \\
\hline MT-4 & 130 & 194 & 16.5 \\
\hline
\end{tabular}

It turned out (see Fig. 1, curve 4) that the irradiation of the nanostructured $\mathrm{Zr}$ after UIT (MT-4) leads to an increase in the yield strength and tensile strength of nanostructured zirconium as compared with the mechanical properties after irradiation, while plasticity remains the same as after the ultrasound (Table).

Investigations of the $\mathrm{Zr}$ structure have shown that, after rolling to $\varepsilon=3.9$, thenanograin structure is formed with a grains size of $\sim 80 \mathrm{~nm}$, which is fairly uniform in volume. The dislocation density in the body of grains is $\rho_{\mathrm{d}} \sim 3.410^{10} \mathrm{~cm}^{-2}$. The main quantity of the dislocations are concentrated at the grain boundaries and triple junctions (Fig. 2,a).

In the creep process of the nanostructured $\mathrm{Zr}$ at $680 \mathrm{~K}$, the initial structure experience a series of transformations (see Fig. 2,b). Initially, the recrystallization processes take place, further new grains are destroyed and the uniform distribution of dislocations with a density of $\rho_{\mathrm{d}} \sim 3.410^{10} \mathrm{~cm}^{-2}$ is formed, and then the cellular structure with misorientations of $\sim 3 \ldots 7$ degrees is formed in their place. As a result, a rather equilibrium structure is formed with a uniform distribution of microstresses. The presence in the deformed material of a high level of internal stresses leads to an acceleration of the kinetics of dynamic recrystallization and a decrease in the temperature of its activation, as compared with the coarse-grained Zr.

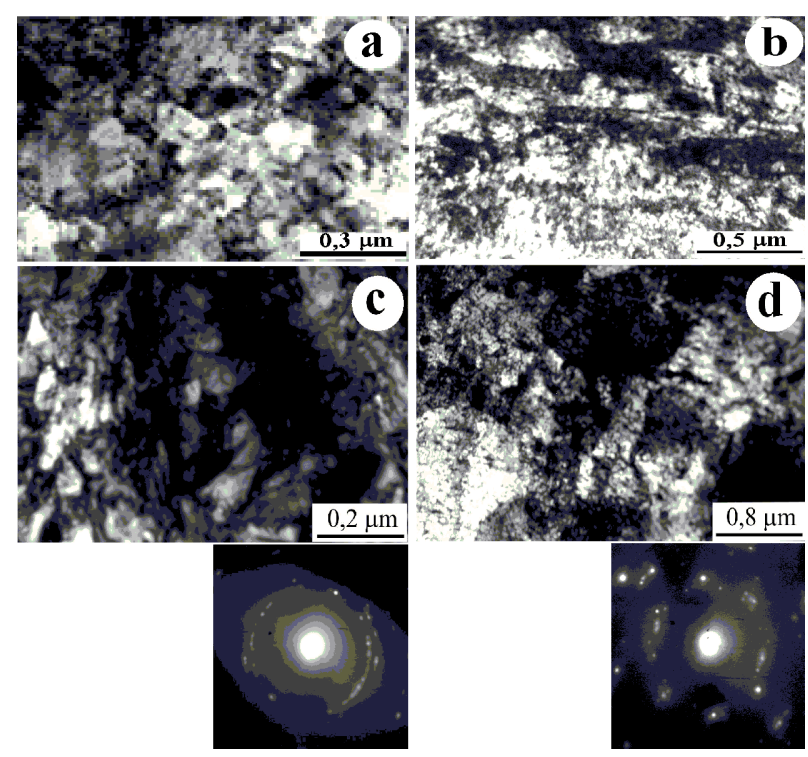

Fig. 2. TEM images of $\mathrm{Zr}$ after follows treatments:

$$
\begin{aligned}
& a-M T-1 ; b-M T-1+\text { creep at } 670 K\left(\sigma \approx 0.9 \sigma_{B}\right) ; \\
& c-M T-2 ; d-M T-2+\text { creep at } 670 K\left(\sigma \approx 0.9 \sigma_{B}\right)
\end{aligned}
$$

Studying the creep process we have determined and calculated the activation volume $(V)$ by the formulae of the thermofluctuational plastic deformation theory [14]. The obtained value is $V \sim 3 \cdot 10^{-21} \mathrm{~cm}^{3}$ and practically does not change with an increase in the applied stress, which means deformation defects do not control the plastic flow of the material and the hardening does not happen in the creep process. This means that during the creep process of $\mathrm{Zr}$, the deformation mechanism changes as the applied stress increases. Our previous experiments [15-17] have shown that the plastic flow of nanostructured materials is conditioned by the joint action of several mechanisms: cross sliding, climbing and annihilation of dislocations near the grain 
boundaries and sliding on the grain boundaries. The contribution from each of these mechanisms into the material deformation depends on the test temperature, applied stress and the grains boundaries state.

Irradiation of nanostructured $\mathrm{Zr}$ by electrons with the dose of $D=5 \cdot 10^{19} \mathrm{~cm}^{-2}$ and an energy $E \sim 10 \mathrm{MeV}$ (MT-2) does not change the nature of the deformation nanostructure, but initiates the return processes. Nanograins have an average size of $\sim 52 \mathrm{~nm}$ $(25 \ldots 220 \mathrm{~nm})$ and are practically cleared of dislocations, the boundaries become smoother and sharper (see Fig. 2,c). The scale of internal stresses has decreased, as evidenced by the disappearance of the contours in the near boundaries areas. The decrease in the level of internal stresses is caused by the activation of return processes, for example, by climbing and annihilation of dislocations within the boundaries and near boundaries areas due to their interaction with vacancies of radiation origin. As a result of these processes, there is also observed the disappearance of "tails" of broken boundaries or their closure to the boundaries of subgrains, the formation of ordered dislocation groups, partly in the form of low-angle boundaries.

It is known [1,4] that the atoms and vacancies appearing under the action of irradiation either are close to each other and easily recombine with the complete destruction of the radiation effect, or move away from each other at considerable distances and the connection between them is lost. In this case, the migration of free defects from the places of formation to sinks (dislocations and interfaces) has a diffusion character directed and accelerated by the action of strong elastic fields.

Moreover, the probability of defects appearing at the boundaries sharply increases, although the efficiency of adsorption by dislocations is also high, as evidenced by a decrease in the dislocation density. A decrease in the average size of grains and an increase in the concentration of the boundary phase are also a consequence of a significant transformation of the structure.

It seems that analyzing the results of structural studies, more informative are the data not of average values of grain size $(d)$, but of the size distribution of the grains array. Fig. 3 shows the grain size distribution curves for rolled, and also rolled and irradiated $\mathrm{Zr}$. It can be seen that the curves in both cases are asymmetric, but after irradiation the degree of homogeneity of the nanostructure has increased.

In the process of creep of irradiated nanostructured $\mathrm{Zr}$ at $670 \mathrm{~K}$, active processes of return and dynamic recrystallization develop (see Fig. 2,d). The size of the new grains is very heterogeneous and ranges from $0.1 \ldots 1 \mu \mathrm{m}$. The internal stresses and the effectiveness of the barriers decreased, additional sources of dislocations were released. As a result, the character of the evolution of nanostructure in the creep process changed somewhat. This is manifested in the more active development of intragrained deformation, accumulation and interaction of new dislocations.

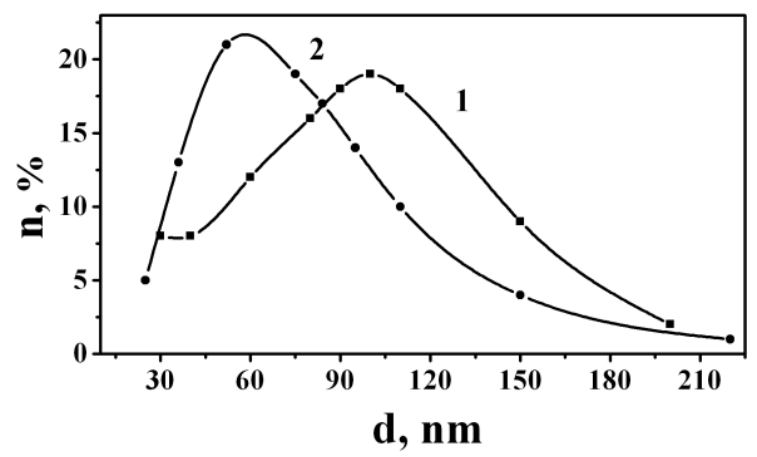

Fig. 3. Spectra of grain size distribution in the samples of nanostructured Zr subjected to the MT-1 (1) and MT-2 (2) treatments

It is necessary to note the similarity of the nature of the transformation of unirradiated and irradiated nanostructures $\mathrm{Zr}$ during the process of creep at $670 \mathrm{~K}$, but there are also differences. The result of deformation of the equilibrium structure formed after irradiation is the striped structure more compensated on orientations and has the boundaries lesser power. It can be seen that the kinetics of dislocation transformations in the less strained nanostructure is accompanied not only by the formation of less powerful clusters of eponymous dislocations, but also by the formation of low-angle boundaries and the emission of dislocations. The magnitude of the activation volume, determined in the creep process of irradiated zirconium, is the same as that of rolling zirconium. In accordance with the value of the activation volume, intragranular plastic deformation is also controlled by the mechanism of thermal activated overcoming by dislocations of the impurities and "forest" dislocations, and as the applied stresses increase, the mechanisms of zirconium plastic deformation change [15-17].

It was shown $[11,12]$ that ultrasonic treatment in the chosen stress relaxation mode does not lead to a noticeable change in the parameters of the initial $\mathrm{Zr}$ nanostructure, but there are signs indicating the beginning of the return processes. The electron microscopic images show clearer fragment boundaries and a low dislocation density inside the fragments (Fig. 4,a). This structure is destroyed in the creep process at $T=670 \mathrm{~K}$. In its place, elongated dense dislocation clusters, weakly misoriented among themselves, are formed (see Fig. 4,c). As a result, the higher material strength is maintained, with an increase in plasticity, creep rate, material homogeneity, and greater structural stability during plastic flow [11-13].

Investigations of the structure have shown that the parameters of $\mathrm{Zr}$ after treatment MT-4 practically did not change, but the level of stresses in the boundaries and near boundaries areas decreased slightly. In the process of creep at $670 \mathrm{~K}$ of $\mathrm{Zr}$ samples after treatment MT-4, the return and the dynamic recrystallization processes similar to those observed in the study of creep of samples after processing MT-2 take place. However, the evolution of the deformed structure observed after these treatments has significant differences (see Fig. $4, \mathrm{c})$. 


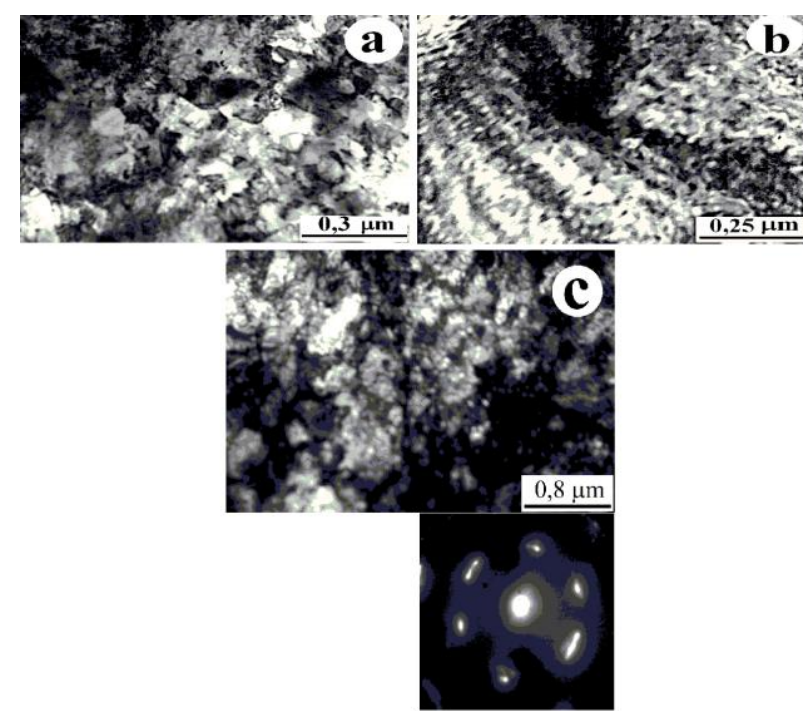

Fig. 4. TEM images of Zr after follows treatments: $a-M T-3 ; b-M T-3+$ creep at $670 K\left(\sigma \approx 0.9 \sigma_{B}\right)$;

$$
c-M T-4+\text { creep at } 670 \mathrm{~K}\left(\sigma \approx 0.9 \sigma_{B}\right)
$$

After MT-4 treatment, the intensity of dynamic recrystallization and the size of newly formed grains decreased due to a lower initial level of internal stresses. The volumes of the recrystallized structure with a grain size of $0.1 \ldots 0.4 \mu \mathrm{m}$ are fixed (see Fig. 4,c).

As a result of reducing the level of internal stresses, the work of the sources intensified, the concentration of new dislocations and the interaction between them increased, resulting in the formation of a loose cellular structure inside the grains. In addition, another slip system was activated, and intragrained dislocation gliding is carried out along two systems.

It should be noted that the magnitude of the activation volume, determined in the creep process of zirconium samples after the MT-4 treatment, is the same as after the two MT-1 and MT-2 treatments that were considered earlier. Consequently, the obstacles controlling the intragrained sliding of dislocations have not changed, i.e. the treatments carried out did not have the significant effect on the energy magnitude and barriers density on the path of dislocations motion.

\section{CONCLUSIONS}

The effect of electron irradiation on the creep and evolution of zirconium nanostructures obtained by the SPD method and previously relaxed by ultrasound is studied.

It has been shown that electron irradiation with the dose of $D=5 \cdot 10^{19} \mathrm{~cm}^{-2}$ and energy $E=10 \mathrm{MeV}$ does not change the character of the deformation zirconium nanostructure, but initiates return processes at the grain boundaries and in the near boundaries areas. This leads to the softening of the material in the creep process at $670 \mathrm{~K}$, while the plasticity practically did not change as compared with the deformed state, which may be due to the active restructuring of the structure and the formation of recrystallization nuclei.

The preliminary relaxation of internal stresses by UIT allows one to retain the sufficiently high level of strength and plasticity of nanostructured $\mathrm{Zr}$ after electron irradiation by reducing the intensity of dynamic recrystallization and activating an additional slip system during creep at $670 \mathrm{~K}$.

Thus, the modification of the structure and properties of nanostructured materials due to the use of relaxation treatment UIT before irradiation improves the operational characteristics of the material and expands the possibilities of their use as structural materials of atomic energy.

\section{REFERENCES}

1. V.N. Voyevodin, I.M. Neklyudov. Evolution of structure phase state and radiation resistance of structural materials. Kiev: "Naukova Dumka", 2006, $376 \mathrm{p}$.

2. D.L. Douglass. The metallurgy of zirconium. M.: "Atomizdat", 1975, $360 \mathrm{p}$.

3. R.Z. Valiev, I.V. Aleksandrov. Nanostructure materials got an intensive plastic deformation. M.: "Logos", 2000, 271 p.

4. V.V. Rybin. Large plastic deformation and fracture of metals. M.: "Metallurgy Publ.", 1986, 224 p.

5. L. Balogh, Donald W. Brown, P. Mosbrucker, F. Long, Mark R. Daymond. Dislocation structure evolution induced by irradiation and plastic deformation in the $\mathrm{Zr}-2.5 \% \mathrm{Nb}$ nuclear structural material determined by neutron diffraction line profile analysis // Acta Materialia. 2012, v. 60, p. 5567-5577.

6. V.I. Sokolenko, A.V. Matz, V.A. Matz. Mechanical characteristics of nanostructured zirconium and zirconium-niobium alloys // Physics of high pressure and technology. 2013, v. 23, N 2, p. 96-102.

7. G.P. Kobilyansky, V.K. Shamardin, S.G. Eryemin, I.M. Kadarmetov, A.V. Medvedev. Long-term strength of E110 alloy shells in the temperature range 673...843 K // Problems of Atomic Science and Technology. Series "Physics of Radiation Effect and Radiation Materials Science". 2001, N 2(79), p. 91-95.

8. D.M. Skorov, U.F. Bichkov, A.I. Dashkovsky. Reactor materials. M.: "Atomizdat", 1979, 344 p.

9. A.V. Matz, V.M. Nenesov, V.I. Sokolenko. Ultrasonic influence on nanostructure in $\mathrm{Zr}-2.5 \% \mathrm{Nb}$ alloy // Problems of Atomic Science and Technology, Series "Physics of Radiation Effect and Radiation Materials Science”. 2011, N 4(74), p. 108-110.

10. I.A. Gindin, G.N. Malik, I.M. Neklyudov. Ultrasonic influence on paramets of monocrystals $\mathrm{Cu}$ hardening // Fizica. 1972, N 2, p. 51-56.

11. V.I. Sokolenko, V.M. Gorbatenko, E.V. Karaseva, A.V. Mats, E.S. Savchuk, V.A. Frolov. Ultrasound influence on creep nanostructured $\mathrm{Zr} / /$ Problems of Atomic Science and Technology. Series "Vacuum, Pure materials, Supreconductors”. 2016, N 1(101), p. 41-44.

12. V.I. Sokolenko, V.M. Gorbatenko, E.V. Karaseva, A.V. Mats, E.S. Savchuk, V.A. Frolov. Effect of ultrasonic impact treatment on the creep characteristics and evolution of the $\mathrm{Zr} 1 \mathrm{Nb}$ alloy nanostructure // Functional Matereals. 2018, v. 25(3), p. 458-462.

13. A. Evans, R. Rawlings. Thermally activated processes in crystals // Phys. Stat. Sol. 1969, v. 34, p. 931.

14. I.F. Borisova, I.N. Butenko, E.V. Karaseva, D.G. Malyhin, A.V. Mats, V.I. Sokolenko, V.A. Frolov. Texture formation peculiarities of zirconium in 
condition of large plastic deformation and its influence on characteristics of creep in the temperatures range 300...700 K // Problems of Atomic Science and Technology. Series "Physics of Radiation Effect and Radiation Materials Science”. 2009, N 2(60), p. 100105.

15. E.V. Karaseva, A.V. Matz, V.I. Sokolenko, V.A. Frolov. Effect of structural instability on creep of zirconium, which subjected to intense plastic // Problems of Atomic Science and Technology. Series "Vacuum, Pure materials, Supreconductors". 2014, N 1(89), p. 106-109.
16. E.V. Karaseva. Influence of structural instability at the creep characteristics of constructing materials // Problems of Atomic Science and Technology. Series "Physics of Radiation Effect and Radiation Materials Science”. 2015, N 5(99), p. 130133.

17. V.I. Sokolenko, E.V. Karaseva, A.V. Mats, E.S. Savchuk, V.A. Frolov. Peculiarities of stress relaxation of nanostructured alloy $\mathrm{Zr} 1 \mathrm{Nb}$ after various influences // Problems of Atomic Science and Technology. Series "Physics of Radiation Effect and Radiation Materials Science”. 2017, N 4(110), p. 79-83.

\title{
ВЛИЯНИЕ ЭЛЕКТРОННОГО ОБЛУЧЕНИЯ НА ЭВОЛЮЦИЮ НАНОСТРУКТУРЫ И ПОЛЗУЧЕСТЬ Zr ПРИ ТЕМПЕРАТУРЕ 670 К
}

\author{
Е.В. Карасева, А.В. Мац, В.А. Мац, Е.С. Савчук, В.И. Соколенко, Д.В. Титов
}

Изучено влияние электронного облучения на ползучесть и эволюцию наноструктуры циркония, полученной методом ИПД и предварительно релаксированной ультразвуком. Показано, что облучение электронами (дозой $D=5 \cdot 10^{19} \mathrm{~cm}^{-2}$ и энергией $E=10 \mathrm{MэВ)} \mathrm{не} \mathrm{изменяет} \mathrm{характер} \mathrm{деформационной}$ наноструктуры циркония, но инициирует возвратные процессы на границах зерен и в приграничных областях, что приводит к разупрочнению материала в процессе ползучести при 670 К. Предварительная релаксация внутренних напряжений ультразвуком позволяет сохранить достаточно высокий уровень прочности и пластичности наноструктурного $\mathrm{Zr}$ после электронного облучения за счет снижения интенсивности динамической рекристаллизации в процессе ползучести при 670 К.

\section{ВПЛИВ ЕЛЕКТРОННОГО ОПРОМІНЕННЯ НА ЕВОЛЮЦЮ НАНОСТРУКТУРИ ТА ПОВЗУЧІСТЬ Zr ПРИ ТЕМПЕРАТУРІ 670 К}

\author{
С.В. Карасьова, О.В. Мац, В.О. Мац, С.С. Савчук, В.І. Соколенко, Д.В. Тітов
}

Виявлено вплив електронного опромінення на повзучість та еволюцію наноструктури цирконію, що отримана методом ІПД і попередньо релаксована ультразвуком. Показано, що опромінення електронами (дозою $D=5 \cdot 10^{19} \mathrm{~cm}^{-2}$ і енергією $E=10 \mathrm{MeB}$ ) не змінює характер деформаційної наноструктури цирконію, але ініціює релаксаційні процеси на границях зерен і в приграничних областях, що призводить до знеміцнення матеріалу під час повзучості при 670 К. Попередня релаксація внутрішніх напруг ультразвуком дозволяє зберегти достатньо високий рівень міцності та пластичності наноструктурного $\mathrm{Zr}$ після електронного опромінення за рахунок зниження інтенсивності динамічної рекристалізації в процесі повзучості при $670 \mathrm{~K}$. 